\title{
Assessment of Public Capital Expenditure Financing in Zanzibar
}

\author{
Mamudu Daffay $^{1^{*}} \quad$ Faida Saleh Juma ${ }^{2}$ \\ 1.Department of Economics, Faculty of Arts and Social Science, Zanzibar University \\ PO box 2440. Zanzibar Tanzania \\ 2.Department of Economics Statistics, Office of the Chief Government Statistician, Zanzibar PO box 2321. \\ Zanzibar Tanzania
}

\begin{abstract}
This study conducted an assessment of public capital expenditure financing in Zanzibar for the period from 1990/91 to 2019/20. Descriptive analysis was used to investigate the type of public capital expenditure undertakings by the RoGZ and major sources of capital expenditure financing while a chi-square test was used to assess performance of public capital expenditure financing in Zanzibar. Findings demonstrated that, development strategies (ZPRP and ZSGRP I-III) put into focus public capital expenditure financing in Zanzibar. It also revealed that, foreign fund and domestic revenue are the major sources of public capital expenditure financing in Zanzibar. The study concludes that Domestic Source, mostly represented by tax revenue in Zanzibar has significantly improved. However, donor funding still heavily dominated public capital expenditure financing in term of estimates. It is further, concluded that, performance of public capital expenditure financing in term of expected values and observed values was not good. Based on the study results, it is recommended that, there is a need for the RGoZ to strengthen its effort in the tax collection and ensure larger share of the tax collected is allocated for public capital expenditure financing in order to reduce over dependency on foreign source for financing capital expenditure in Zanzibar.
\end{abstract}

Keywords: Public Capital Expenditure, Domestic revenue, Foreign revenue, Chi-square

DOI: $10.7176 / \mathrm{JESD} / 12-2-06$

Publication date: January $31^{\text {st }} 2021$

\section{Introduction}

Government expenditure could be broadly classified into recurrent expenditure and capital expenditure and according to Liang (2015) is the expenditure that is used for stimulating economic growth and social welfare in the country. The government expenditure which occurs regularly throughout the year is referred to as recurrent expenditure, while Capital expenditure on the other hand is the expenditures of government on the acquisition of things of permanent nature. They include all expenditure on capital projects such as buildings, construction of roads, bridges and all permanent structures and assets. OXFAM and DFI (2020) listed three sources of public capital expenditure financing which are: foreign grants from other governments or international organizations; net external finance which include bonds, loans and any other liabilities; and lastly, government domestic revenue. Public capital expenditures in Zanzibar are mainly financed by domestic sources which are classified as Government fund and the sum of grants and external finance disbursements to the Revolutionary Government of Zanzibar (RGoZ) which are classified as Donor Fund (DF). Most recent Government Budgetary Operations data from the Bank of Tanzania (BOT 2020) indicate the RGoZ in 2018/19 continued to implement various measures to strengthen tax administration and compliance, as well as to improve expenditure management. As such, the performance of the budget was generally satisfactory.

The Bank report indicated that, revenue collections and grants from development partners increased, leading to a resources envelope of TZS 791.1 billion, of which TZS 748.4 billion was revenue and the balance was grants. The revenue collection increased 9.1 percent over the amount collected in the preceding year. Tax revenue accounted for 87.3 percent of revenue collection, and only income tax was on target. Foreign grants amounted to TZS 42.1 billion, more than projected by 19.9 percent. Non-tax revenue was TZS 64.7 billion, surpassing the target by 18.4 percent largely owing to more than projected dividend from public corporations. On expenditure side, The BOT (2020) noted that expenditure of the RGoZ in 2018/19 amounted to TZS 1,131.5 billion, falling short of estimates by 14.0 percent. Out of the government expenditure, TZS 702.8 billion was spent on recurrent obligations, almost as estimated at TZS 702.1 billion, while TZS 428.7 billion was expenditure on development projects and was below estimates by 30.1 percent. MoFP-T (2016) argued that, public capital expenditure in Tanzania has relied largely on capability to mobilize from both domestic and external sources. Such sources include government revenue, borrowing, grants, donations and private as well as nongovernmental financial flows.

Based on lessons on budget financing, capital expenditure has always been first victims of budget cuts following unexpected emergency expenditures and shortfalls in resources mobilization. Ortiz-Ospina and Roser (2016) noted that, relative to low-income countries, government expenditure in high-income countries tends to be much larger (both in per capita terms, and as share of GDP, and it also tends to be more focused on social protection. Public-private partnerships (PPP), in particular, have become an increasingly popular mechanism for 
public capital expenditures financing including design, build and operate infrastructure projects. RGoZ and UNICEF (2018) indicate that, the share of Government capital expenditure in the Zanzibar national budget increased from 17 per cent to 46 per cent between 2013/14 and 2017/18. However, budget execution rates for the development budgets have been declining since FY 2013/14. The development budget which executed 90 per cent of its budget in FY 2013/14 experienced weak performance with the execution rate which was standing at 55 per cent (FY 2016/17). Furthermore, the development budget has been expanding rapidly but is still dominated by Development Partners (DPs) which put its execution at a very high risk if they fail to fulfil their promises. Particular in Zanzibar, foreign fund and domestic revenue are the major sources of capital expenditure financing. However, tax revenue collection in Zanzibar has been improving over the past five years. But Despite such improvement, capital expenditure is still heavily dominated by Donor funding (89 per cent in 2017/18). This situation has raised a question about the effectiveness of domestic revenue (in particular tax revenue) for financing capital expenditure in Zanzibar. Therefore, this study intends to focus on an assessment of capital expenditure financing in Zanzibar. The findings of this study will help the Government of Zanzibar on how to enhance capital expenditure financing it will be valuable inputs for future researchers who are interested on assessing the capital expenditure financing in Zanzibar and Tanzania at large.

\section{Literature Review}

Ortiz-Ospina and Roser (2016) noted that, there are four broad periods in which Government spending can be distinguished. First World War, between 1915 and 1945, Second World Wars and between 1945 and 1980, public spending grew particularly fast. This was the result of growth in social spending; and was largely made possible by historical increases in government revenues over the same period. Since 1980 the growth of government expenditure has been slowing down in early-industrialized countries. However, in many countries, public spending as a share of GDP is higher today than before those specified period with spending exceeding 50 percent in many European countries.

Many studies including; Alan T. Peacock and Jack Wiseman (1961), Robert Solow (1956), Professor Arthur Cecil Pigou (1932) and Hough Dalton (1965) as well as the classical and Keynesian economists have poured light on the nexus of government spending and national income. Adolf Wagner in 1893 for example stated that during the industrialization process, as the real income per capita of a nation increases, the share of public expenditures in total expenditures increases. Wagner pointed out that public spending is determined by the growth of national income. Hence, it is national income that causes public expenditure.

Furthermore, Gupta et al. (2005); Clement, et al. (2003); Baldacci, et al. (2004); and Kumar et al. (2007) concluded that, the principal determinants of public expenditure on investment include level of development, and the size of the government. which is reflected by the share of tax revenue in GDP. High tax revenue reflects the availability of resources required to finance government expenditure. Higher tax revenue is also associated with increased public investment spending on physical and human capital development (Sturm, (2001); Khattry, (2003)). There have been studies dealing with assessment of capital expenditure financing. though specific studies of these kind on Zanzibar are yet to emerge.

\section{Materials and Methods}

This study adopted a descriptive research design. The reason being that it can answer questions of what, when, where, and how. The descriptive research is an appropriate choice for this research because the research aim is to identify characteristics, frequencies, trends, and categories. This study was conducted in Zanzibar assessing public expenditure financing for the period from 1990/91 to 2019/20. mainly secondary data collected from the Zanzibar's' Ministry of Finance and Planning were used in this study. The data series that was used includes: Nominal Gross Domestic Product, Total Government Expenditure, Total Capital Expenditure, Domestic Revenue, Tax Revenue, as well as Grants and Aids. to undertake assessment of capital expenditures financing in Zanzibar, descriptive analysis and chi-square test were employed to carry out the assessment.

\section{Summary of Key Findings}

\subsection{Type of Public Capital Expenditure Undertaking}

In Zanzibar, Capital expenditure undertaking was implemented through programmes, projects and initiatives that fall under the following five Key Results Areas(KRA):

- Key Results Area A - Enabling Sustainable and Inclusive Growth;

- Key Results Area B - Human Capital Development aiming;

- Key Results Area C - Quality Services for All;

- Key Results Area D - Attaining environmental sustainability and climate resilience; and

- Key Results Area E - Adhering to Good Governance Principles.

This study revealed that enabling sustainable and inclusive growth (KRA A) was the most highly emphasized during implementation of ZPRP, ZSGRP I, ZSGRP II and ZSGRP III. In this area, agriculture, industry and 
services remained the priority sectors in achieving sustainable economic growth. Human Capital Development (KRA B) was second prioritized in ZPRP, ZSGRP I and ZSGRP II were 40.5 percent of the total capital expenditure spending were allocated to this area. In Key Results Area C, Quality service for all; emphasizes on programmes and projects for adequate provision of healthcare, education, decent housing, safe water, and sanitation and protection services, along with reliable energy and infrastructure was second prioritized in ZSGRP III for which 35.8 percent of capital expenditure spending were allocated to this area. Taking into consideration size and geographical location of Zanzibar, the environment and climate change in particular (KRA D) was and still is a major threat to small island states like Zanzibar. However, in terms of capital expenditure financing, this area was not much noticeable except in period from 1990/91 to 2001/02 only 9.0 percent of capital expenditure spending estimates was allocated to this area. Adhering to Good Governance Principles (KRA E) came into focus as a national priority during implementation of ZSGRP III were 9.3 percent of capital expenditure spending estimates were allocated to this results area. This area is about accountability and transparency, along with enabling citizens to have the requisite knowledge and knowledge to demand and create positive change. As seen in figure one.

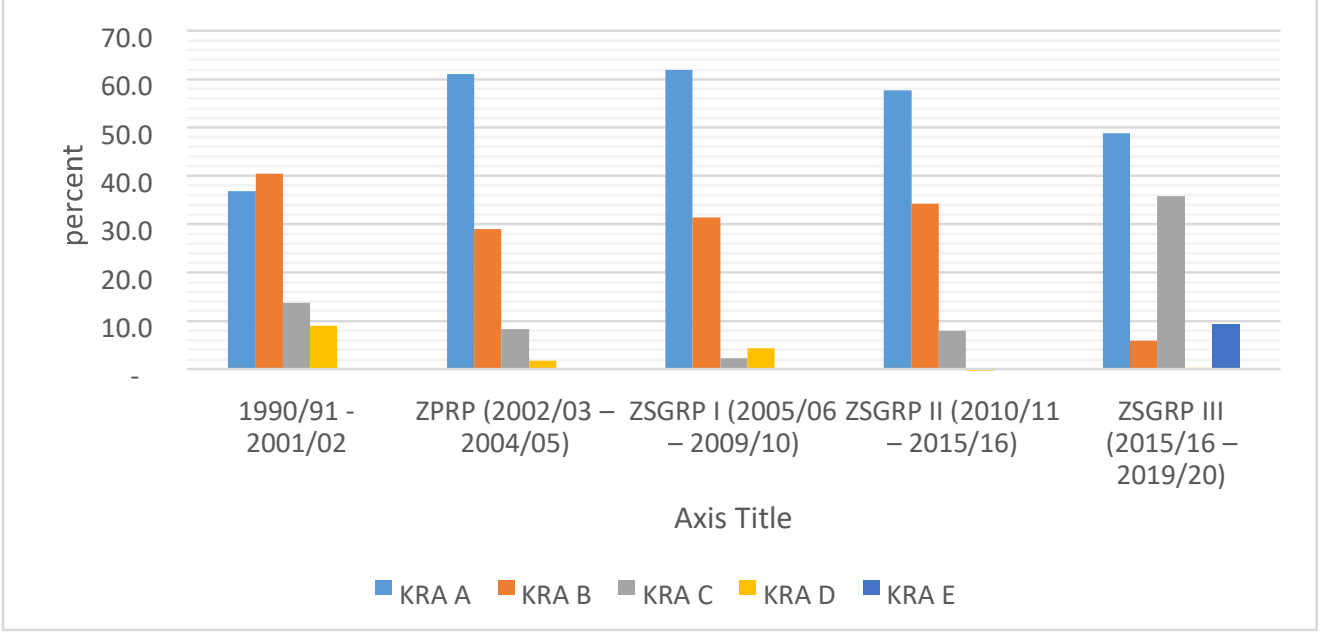

Figure 1: Percentage of Capital Expenditure Estimates by Key Results Area

\subsection{Sources of Public Capital Expenditure Financing in Zanzibar}

The formulation and adoption of ZPRP and the three series of ZSGRP attracted huge donor support in terms of promises. Regardless of donor promises to support government efforts, execution of foreign fund for supporting capital expenditure financing in Zanzibar was not reliable. Foreign fund execution rate was highly volatile fluctuating annually within the range from 0.55 percent in 1990/91 to 88.32 percent in $2019 / 20$. Execution rates of local fund were higher compared with foreign fund execution throughout the study period. Local fund execution rates were even above $100 \%$ in the period of implanting ZSGRP I and ZSGRP II. In this period RGoZ top up fund for executions of development programmes and projects. The increase of domestic revenue exhibits good performance in the revenue collection from a reliable and expanding domestic sources of revenue; while Tax revenue continues to be a major source of domestic revenue in Zanzibar as demonstrated by proportion of tax revenue in the domestic revenue which remained above 85 percent from 1994/95 to 2019/20. figure two demonstrated the execution rate of capital expenditure for both local and foreign funds. 


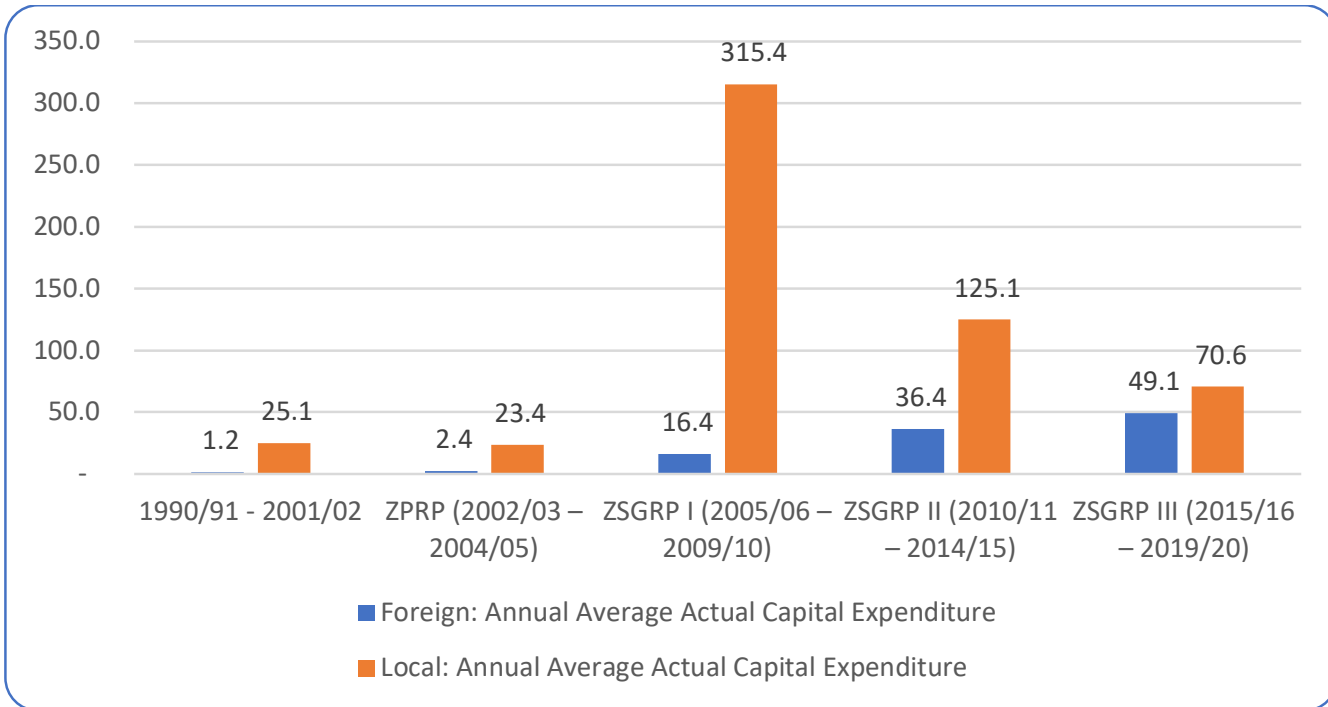

Figure 2: Execution Rates of Capital Expenditure Spending (in percent) by Source, 1990/91 - 2019/2020

\subsection{Performance of Public Capital Expenditure Financing in Zanzibar}

Chi square test was used to test the statistical significance of performance of capital expenditure financing. The chi square test is employ in a wide variety of situations; Including situations when we consider the difference between the observed and the expected outcomes of a distribution. This difference leads us to a computed value of the chi-square statistic, and then compare the value of the statistic with critical points of the chi-square distribution and make a decision. The formula of the statistic is given as equation

$$
\chi^{2}=\frac{\sum(O-E)^{2}}{E}
$$

Table 1 shows that at $\alpha=0.05$ and $\mathrm{df}=29$, the critical value observed in three case was 42.557 . However, in testing Case 1 chi statistics was 1,591,100.54, Case 2 was 1,200,124.59 and case three was 929,120.55. In all the three cases of capital expenditure financing (total, local and foreign), the chi square test statistics were greater than the critical value (at $\alpha=0.05$ ), therefore we reject the null hypothesis of no difference between budget estimates and actual expenditures. Thus, the results suggest that there are really observed differences in performance between expenditure estimates as approved by authoritative bodies that go with the 'actual' expenditures as allocated by implementing bodies.

Table 1: Summary of chi square test results

\begin{tabular}{|l|c|r|r|}
\hline & \multicolumn{1}{|c|}{ CASE 1 } & CASE 2 & \multicolumn{1}{c|}{ CASE 3 } \\
\cline { 2 - 4 } & $\begin{array}{c}\text { Total Capital } \\
\text { Expenditure } \\
\text { Estimates and Total } \\
\text { Actual Capital } \\
\text { Expenditure }\end{array}$ & $\begin{array}{c}\text { Local Capital } \\
\text { Expenditure } \\
\text { Estimates and Actual } \\
\text { Local Capital } \\
\text { Expenditure }\end{array}$ & $\begin{array}{c}\text { Foreign Capital } \\
\text { Expenditure } \\
\text { Estimates and Actual } \\
\text { Foreign Capital } \\
\text { Expenditure }\end{array}$ \\
\hline Level of Significance $(\alpha)$ & 0.05 & 0.05 & 0.05 \\
\hline Degree of freedom $(\mathrm{df})$ & 29 & 29 & 29 \\
\hline Critical Value $(\mathrm{cv})$ & 42.557 & 42.557 & 42.557 \\
\hline Chi Square Statistics & $\mathbf{1 , 5 9 1 , 1 0 0 . 5 4}$ & $\mathbf{1 , 2 0 0 , 1 2 4 . 5 9}$ & $\mathbf{9 2 9 , 1 2 0 . 5 5}$ \\
\hline
\end{tabular}

The results reveal there is not sufficient evidence to support the null hypothesis or openly fail to support the hypothesis of no difference of budget estimates and actual disbursement. As indicated that in all case the estimates of the total, local and foreign capital expenditures there is significant mark differences with their respective actual expenditures. Interpretation suggest that there are really observed differences between expenditure 'estimates' (as approved by the Zanzibar House of Representatives) that goes with the 'actual' expenditures (as allocated by MoFP). This is true to both, local and foreign capital expenditures, and consequently true for3 total capital expenditures. Such results imply negative impact on the implementation of programmes and projects under each key results area. The situation hinders overall objective of poverty eradication and also delayed generation of high economic growth and improved delivery of social services in time. 


\section{Conclusions}

On five type of capital expenditure undertaking by the RoGZ, it is concluded that: ZPRP and the three series of ZSGRP (I-III) put into focus capital expenditure financing in Zanzibar. In terms of priorities, this study result pointed out that: in ZPRP, the prioritized areas are: Enabling Sustainable and Inclusive Growth(KRA A) and Creating a strong human resource base with the right knowledge skills, attitudes and values to enhance productivity and competitiveness (KRA B); ZSGRP I also focus on Enabling Sustainable and Inclusive Growth (KRA A); Creating a strong human resource base with the right knowledge skills, attitudes and values to enhance productivity and competitiveness (KRA B); but went further to include the environment and climate change in particular (KRA D). The three most prioritized areas in ZSGRP II, are Enabling Sustainable and Inclusive Growth (KRA A), Creating a strong human resource base with the right knowledge skills, attitudes and values to enhance productivity and competitiveness (KRA B) and Adhering to Good Governance Principles (KRA C). For ZSGRP III, three most focused areas are: Enabling Sustainable and Inclusive Growth (KRA A), Adhering to Good Governance Principles (KRA C) and the environment and climate change (KRA E) in particular.

On the sources of capital expenditure financing in Zanzibar, it was concluded that increasing dependency or higher levels of foreign source for capital expenditure financing may put Zanzibar at high risk of devoting to the donor conditionality. Some donor countries dedicate aid with their own interest comprising humanitarian, political, commercial, military and economic motives. Donor motive based on moral and humanitarian reasons whereby donors intend to enhance social welfare should be promoted in Zanzibar so as to support the efforts of RGoZ in the capital expenditure financing, while aid with political and military motives should be critically examined. Tax revenue collection in Zanzibar has significantly improved; demonstrated by 85 percent proportion of tax revenue in the domestic revenue which remained above from 1994/95 to 2019/20. Increasing tax revenue collection in Zanzibar is critical in the process of decreasing resources from foreign donor. However, despite domestic revenue being increasing to finance capital expenditure, donor funding estimates still heavily dominated capital expenditure financing, though execution rates of local fund were higher compared with foreign fund execution throughout the study period.

On performance of capital expenditure financing in Zanzibar, it is concluded that there are significant observed differences between expenditure 'estimates' that goes with the 'actual' expenditures for both, local and foreign capital expenditures, as well as in total capital expenditures. Hence performance of capital expenditure financing in Zanzibar in term of expected value and observed value, though encouraging, is not good, and needs to improve.

\section{Recommendations}

Based on the results of this study, there is the need for the RGoZ to strengthen its effort in the tax collection and ensure larger share of the tax collected is allocated for capital expenditure financing in order to reduce over dependency on foreign source for financing capital expenditure in Zanzibar. Increasing capital expenditure estimates should be reflected in the total actual capital expenditure. Similar attribute should be observed in the local and foreign components of the capital expenditure financing in Zanzibar.

\section{BIBLIOGRAPHY}

Alan T. Peacock \& Jack Wiseman (1961). The Growth of Public Expenditure in the United Kingdom, Princeton University Press Volume ISBN: 0-7014-071 XVolume URL: http://www.nber.org/books/peac61-1

Baldacci, E., Clements, B., Gupta, S. and Mulas-Granados, C. (2004). "Front- Loaded or Back-Loaded Fiscal Adjustments: What Works in Emerging Market Economies." IMF Working Paper 04/157, Washington: IMF

BOT (2020). Annual Report for Financial Year 2019/2020

Clement, B., Bhattacharya, R. and Nguyen, T. Q. (2003). "External Debt, Public Investment, and Growth in LowIncome Countries.” IMF Working Paper 03/249, Washington, D.C., IMF

Esteban Ortiz-Ospina (2016). "Government Spending”. Published online at OurWorldInData.org. Retrieved on September 2020 from: 'https://ourworldindata.org/government-spending'

Gupta, S., Clement, B., Baldacci, E. and Mulas-Granados, C. (2005). "Fiscal Policy, Expenditure Composition, and Growth in Low-Income Countries.” Journal of International Money and Finance

Hough Dalton (1965). Principles of public Finance-Routledge and kagan paul ltd., London

Khattry, B. (2003). "Trade Liberalization and the Fiscal Squeeze: Implications for Public Investment." Development and Change.

Kumar, M. S., Leigh, D. and Plekhanov, A. (2007). "Fiscal Adjustments: Determinants and Macroeconomic Consequences.” IMF Working Paper 07/178, Washington: IMF.

Liang, See Yong (2015). Government Development Expenditure and Government debt in Malaysia.

OXFAM and DFI (2020). Who is spending what on the Sustainable Development

Goals. Retrieved on September 2020 from: https:/www.governmentspending

Pigou, A. C. (1932). The Economics of Welfare. London: Macmillan. 4thedition. 
RGoZ and UNICEF (2018). Zanzibar - National Budget Brief. Retrieved from: https:/www.unicef.org/tanzania/media/1336/file/UNICEF-Zanzibar-2018-National-Budget-Brief.pdf.

Solow, Robert M. (1956). "A contribution to the theory of economic growth." The quarterly journal of economics70, no. 1: 65-94.

Strum, J. (2001). "Determinants of Public Capital Spending in Less-Developed Countries." University of Groningen \& CE Sifo Munich. 